\title{
$\underline{\mathrm{O} J \mathrm{ED}}$
}

Volume 5, Issue 1 (2020), pp. 141-149

International Journal of

Multidisciplinary Perspectives in Higher Education ISSN: 2474-2546 Print/ ISSN: 2474-2554 Online https://ojed.org/jimphe

\section{Race(ing) towards Legal Literacy for (Im)migration amidst COVID-19}

\author{
Patriann Smith \\ University of South Florida/United States of America
}

\author{
S. Joel Warrican \\ University of the West Indies, Cave Hill Campus/Barbados
}

\begin{abstract}
Historically and contemporarily, immigration laws have disproportionately affected immigrant faculty and students of color because such laws often inadvertently function as racial policy. (Critical) legal literacy enacted via a bottom-up approach can help to address such laws. In this paper, we argue that higher education institutions are uniquely positioned to use critical legal literacy as a tool of advocacy for immigrant faculty and students of color amidst the adverse effects of COVID-19.
\end{abstract}

Keywords: anti-racist, legal literacy, race, immigration, Black immigrant literacy, higher education, law

\section{RACE(ING) TOWARDS LEGAL LITERACY FOR (IM)MIGRATION AMIDST COVID-19}

Our attitude towards immigration reflects our faith in the American ideal. We have always believed it possible for men and women who start at the bottom to rise as far as the talent and energy allow. Neither race nor place of birth should affect their chances.

Robert F. Kennedy 
When the world learned, in 2018, of the banning of citizens in five majority-Muslim nations [Iran, Libya, Somalia, Syria and Yemen] from entry to the US, there was shock, outrage and outcry. On January 31, 2020, the world saw another ban from the US, evoking similar reactions. This time, Nigeria, among other nations [Eritrea, Kyrgyzstan, Myanmar, Sudan and Tanzania], was targeted. A third ban was enacted on April 22, 2020, barring immigrants whose migration, it was thought, would be "detrimental to the interests of the United States" (The White House, 2020a). And as we write this essay, The Wall Street Journal reports an emerging order against aliens (yes, that's what we are called!) that "temporarily bar[s] new immigrants on a slate of employment-based visas, including the $\mathrm{H}-1 \mathrm{~B}$ for high-skilled workers," citing the need to "protect unemployed Americans from the threat of competition for scarce jobs from new lawful permanent residents" (The White House, 2020b). Meanwhile, construction of the USMexico multibillion-dollar southern border wall continues, unaffected by COVID-19 (Lakhani, 2020).

As the Majority World (see Panelli, Punch, \& Robson, 2007) laments anti-immigration laws implemented in one of the most powerful nations of the Minority World, often overlooked is the racial categorization of the people targeted by such laws. As of 2019, the majority of immigrants to the US [Mexican, Indian, Filipino, Chinese, and Vietnamese] (The Migration Policy Institute, 2020) were people of color. And Bloomberg reported in 2015 that Africans, followed by Asians, both peoples of color, were the most educated immigrant sub-populations in the United States (Bloomberg, 2015).

Recent emerging decisions regarding immigration, advanced as part of anti-immigrant US policy that inadvertently targets people of color, echoes a historical narrative of "US immigration laws and procedures as "racial" policies" (see Blumenfeld, 2018, p. 1). This narrative, made explicit in 1882 by excluding Chinese and other Asian immigrants, has been repeated in instances such as: (a) the "Gentleman's Agreement" to decrease Japanese immigrants in 1907; (b) The Immigration Act to prohibit immigration from Asian countries in 1917; (c) the Johnson Reed Immigration Act excluding "[B]lacks of African descent from entering the United States" and restricting immigrants from Asia, Northern and Southern Europe which included individuals from the "Hebrew race", Jews, Poles, Italians, Greeks, and Slavs in 1924; (d) the "Mexican Repatriation" efforts of 1920-1930; (e) the mass deportation of Mexicans in 1954; and (f) the legislation SB 1070 mandating that "police officers stop and question people about their immigration status if they even suspect that they may be in this country illegally, and criminalize undocumented workers who do not possess an "alien registration document"" (Blumenfeld, 2018, p. 9). 
In large part, the narrative reflects how immigration law in the US inadvertently operates under the guise of supposed American freedom while reinforcing the racialization and policing of Black and brown bodies across international boundaries. The racializing and policing of immigrants of color through the use of injurious immigration laws has created an environment of discomfort where visitors are made to feel unwelcome. Such unease is felt even by immigrants who enter the country legally and are in positions where they can contribute to national development. In some cases, these immigrants are in fact bringing in significant sums to the economy. For example, international students and scholars are known to contribute billions in fees and living expenses (Institute for Immigration Research, 2019). It is these group of immigrants (students and scholars, such as university faculty) that we are interested in highlighting in this paper, with special emphasis on those of color. As Black scholars ourselves, we focus primarily on immigrants of color, not only because we identify with these groups, but also because these recent immigration laws seem to unfairly target them.

A major issue for these Black and brown immigrant students and faculty in the academic setting is not just the discomfort, but also the sense of accompanying helplessness. They often do not know how to navigate a system where the immigration laws are seemingly set to make them uncomfortable or even force them to leave the country. It is as if they find themselves in a strange new world, a world in which they are prepared to contribute legally, but the laws are weaponized against them. Very troubling is that their colleges or universities (including, the administrators and faculty and students who are citizens) often do not seem to care sufficiently to show empathy for their plight and moreover, to advocate for them with the US Citizenship and Immigration Service (USCIS). In this paper, we are calling for a greater involvement of colleges and universities in helping Black and brown immigrant students and faculty to tackle the challenges (and sometimes, even upheavals) in their lives caused by immigration laws. This, we believe, can be done by using legal literacy as a tool of advocacy for these immigrants. We believe that through legal literacy, universities can educate the immigrants to navigate this turbulent period. This tool can also be used to educate students and faculty who are citizens of the US, as well as college and university administrators. This, we believe, is important in an environment where the immigrant students and faculty need empathy within their academic community, an empathy that we believe can then lead to advocacy. Through this paper, we also make the case that it is incumbent on the university to value its immigrant students and faculty of color to the point where they take on the responsibility to provide legal literacy education to USCIS in an effort to raise sensibilities about the unjust nature of the laws leveraged and how they might best execute them. Through this paper, our intention is not just to shed light on these laws and their effects but also to put forward a tangible action (legal literacy education) that we 
believe can go a long way to offer relief to immigrant students and faculty of color.

\section{Is there a role for the US academy in anti-racist immigration policies and procedures?}

Across the academy, during a time when COVID-19 and current racial unrest have further made visible the stark realities of immigrant students and faculty, the majority of whom are people of color (Yancy, 2020), US academia as a whole remains under scrutiny. The Majority World watches, waiting with anticipation to see how US higher education entities will use legal literacies in ways that counter such racialization, as well as the antiimmigration stances by which they are bolstered. Kofi Annan, former Ghanaian diplomat who served as the seventh Secretary-General of the United Nations from January 1997 to December 2006, and was co-recipient of the 2001 Nobel Peace Prize, declared literacy as a vehicle for supporting the rule of law (Kofi Annan Foundation, 2011). Literacy for the rule of law potentially restricts the arbitrary exercise of power by subordinating it to well-defined and established laws.

We concur with Kofi Annan and go further, asserting the need for legal literacy, "the ability to read and write legal arguments" (Peña Carranco, 2016, p. 5), which creates a general awareness about specific and applicable laws or rules that function as enforceable "legal rights and duties," as well as how their violation becomes subject to legal action (Pulikuthiyil, 2012, p. 96). We acknowledge also, the need for legal literacy that:

goes beyond the development of a basic legal competence and implies the acquisition of knowledge, understanding and critical judgment about the substance of law, legal process and legal resources, enabling and encouraging the utilization of capacities in practice. (Manley-Casimir, Cassidy \& Castell, 1986, p. 90)

For us, the extension of legal literacy -- critical legal literacy, is also important, as this dimension adds a "critical perspective to the knowledge of how the tools of legal literacy function," and observes "that the law, its concepts, and ideas may be improved by critique and also by using the tools of legal literacy to bring about progressive change within existing legal systems" (Zariski, 2014, p. 15).

Fortunately (and thankfully!), recently, numerous statements have emerged, as they often do, from institutions and organizations of higher education, as well as labor unions and associations, reaffirming a clear commitment to anti-racist policies and practices. It is therefore reassuring and reasonable to view academia as a key vehicle for enacting critical legal literacy in ways that challenge the persisting racialization of Black and brown bodies, increasingly visible via an anti-immigrant stance. This imperative is particularly compelling given that: (a) $22 \%$ of the faculty in academia are foreign-born; (b) academia is not "subject to the same 
numerical limits on visas as many other employers"; (c) international students contributed \$36 billion dollars to the US economy in 2016-2017 alone (Institute for Immigration Research, 2019, p. 2); and (d) academia reflects 1,095,299 international students, most of whom are students of color (i.e., Chinese, Indians, South Koreans, Saudi Arabians) and whose recent increases also constitute students of color (i.e., Bangladeshi, Brazilians, Nigerians, Pakistani) (Institute of International Education, 2020).

\section{Towards critical legal literacy for anti-racist immigration policy}

In the end, we will remember not the words of our enemies, but the silence of our friends.

Martin Luther King, Jr.

As Black Caribbean scholars, one of whom is a member of the US immigrant faculty and a former international student of color (first author), we empathize with our peers and students, many of whom have long since endured racialization against their languages and cultures as immigrants (see Smith, 2018, 2019, 2020), but who still attempt to use the legal literacies that they muster to thrive. As an immigrant population of students and faculty who now call the US home, this population works tirelessly (ask anyone you know!) but often has little to no recourse for addressing racialization (Smith, In press), grappling with what Gunnar Myrdal referred to as the "American dilemma," where "an overriding commitment to democracy, liberty, freedom, human dignity, and egalitarian values, coexist[s] alongside deep-seated patterns of racial discrimination, privileging white people, while subordinating peoples of color" (Blumenfeld, 2018, p. 12; Myrdal, 1944).

We believe that while empathy is necessary, it is not sufficient. As stated earlier, firm action must be taken by higher education institutions to support immigrant students and faculty of color. We have made the call for legal literacy to counter the scourge of what we consider racist immigration laws. Now, more than ever, immigrant populations of color within higher education are more than likely experiencing elevated levels of anxiety from both anti-immigrant and racialized rhetoric at this time. In this critical time, they will need a level of support than can be provided through critical legal literacy, which we believe should help to bring a sense of stability in the efforts of immigrant students and faculty of color to continue contributing significantly and effectively to US academic institutions. The urgency of this call is even more critical given the recent refusal of a green card to lawabiding Canadian immigrant and assistant professor, Dr. Julia Iafrate, despite her fight as a medical doctor on the frontlines against COVID-19 (Bista, 2020; Brito, 2020; Shoichet, 2020).

Considering the above, the question here really is how can higher education institutions ensure the provision of the critical legal literacy education of which we advocate. We believe there are several things that 
can be done. We believe that all faculty, students, staff and administrators must be exposed to training in legal literacy. For the various groups the training will have different purposes but the core of the training will be to raise legal literacy levels. We believe that the immigrant student and faculty's exposure to this training would help them to heighten their awareness of the immigration realities and to help them to navigate in this challenging environment. In the case of American students, faculty, staff and administrators, this training hopefully would enable them to get an understanding (that is often nonexistent) of the plight of the immigrant student and faculty. The aim is to bring these stakeholders to the point where they can not only empathize with, but go even further to advocate for the causes of the immigrant student and faculty of color. We believe that such training should be systemic forming a part of modules in student courses, staff and student orientation and even continuing professional development programs for staff. It should no longer be sufficient for the leadership of higher education to be satisfied with the provision of the traditional curriculum in their institutions. They must now ensure that the curriculum exposes all students (immigrants and citizens) to the realities of racism against immigrants of color and presents a pedagogy that helps to challenge and combat discrimination of any kind. We further advocate that institutions and organizations in higher education such as the AAUP that often take a top-down approach to legal literacy (Fifolt, Solomon, \& Owens, 2010), as well as labor unions and associations, can adopt a bottom-up approach that uses critical legal literacy, in collaboration with racialized immigration populations, to educate-up, challenging pervasive antiimmigration stances which adversely affect immigrant students and faculty of color. They are well positioned to do so as they:

1. Determine how they might work more actively, in consultation with the USCIS to reform national immigration laws and policies that reinforce the racialization of immigrant faculty and students of color in the United States;

2. Become more committed to the plight of immigrant faculty by actively seeking to provide legal representation for immigrant faculty and students of color who are often at the mercy of an immigration system that appears to be bolstered by systemic racism;

3. Conduct equity audits of immigration laws enacted regarding immigrant faculty and students of color with a view to negotiating with USCIS about how the adverse effects of such laws in higher education can be averted;

4. Develop a more intentional communication system surrounding legal literacy that exposes mainstream faculty, students and staff to updates regarding immigration law, the challenges it poses for immigrant faculty and students of color, and engaging mainstream populations with legal 
literacies needed to support the immigrant populations on their campuses.

The drastic measures recently taken to exclude people of color from migrating to the United States, much like the slave trade, wars, and civil unrest that have destroyed the familial ties of people of color for so long, continue to indefinitely separate many international faculty and students from their families. In the end, empathy matters, but it is change in our legal systems that last.

\section{References}

Bista, K. (2020). Let us stand with Julia! International Students or Immigrant Workers in the United States. Journal of International Students, 10(2), i-iv.

Blumenfeld, W.J. (2018). United States immigration laws \& procedures as "racial" policies. Retrieved from https://www.academia.edu/37618963/United_States_Immigrat ion_Laws and Procedures as Racial_Policies.

Brito, C. (2020, May 7). New York City doctor denied green card even while treating coronavirus patients. CBS News. https://www.cbsnews.com/news/julia-iafrate-doctorcoronavirus-battle-visa-denied/

Fifolt, M., Solomon, A., \& Owens, A. (2010, September). Navigating the personal- professional divide in student affairs: Moving beyond the middle. NetResults: Critical Issues for Student Affairs

Practitioners.

http://www.naspa.org/pubs/mags/nr/default.cfm

Institute for Immigration Research. (2019, January). A portrait of foreign-born teachers in the United States. https://www.immigrationresearch.org/system/files/Teacher_Pa per.pdf.

Institute of International Education. (2019, November 18). Number of international students in the United States hits all-time high. https://www.iie.org/Why-

IIE/Announcements/2019/11/Number-of-International-

Students-in-the-United-States-Hits-All-Time-High

Kofi Annan Foundation. (2011, September 15). Promoting literacy to support the rule of law. https://www.kofiannanfoundation.org/in-the-news/promotingliteracy-to-support-the-rule-of-law/

Lakhani, N. (2020, March 22). Construction of US-Mexico border wall proceeds despite coronavirus pandemic. The Guardian. 
https://www.theguardian.com/us-

news/2020/mar/22/construction-us-mexico-border-wallcoronavirus-pandemic

Manley-Casimir, M.E., Cassidy, W., \& de Castell, S. (1986). Legal literacy: Towards a working definition. Report Submitted to the Canadian Law Information Council. Ottawa: Canadian Law Information Council.

The Migration Policy Institute. (2020). The top sending countries of immigrants in Australia, Canada, and the United States. https://www.migrationpolicy.org/programs/data-hub/topsending-countries-immigrants-australia-canada-and-unitedstates the migration policy institute.

Myrdal, G. (1944). An American dilemma: The Negro problem and modern democracy. New York, NY: Harper \& Row.

Panelli, R., Punch, S., \& Robson, E. (Eds.). (2007). Global perspectives on rural childhood and youth: Young rural lives.

London: Routledge.

Peña Carranco, L. E. (2016). The concept of legal literacy amongst educators in Canada. (Doctoral dissertation, University of British Columbia).

Pulikuthiyil, G. (2005). Legal literacy: Social empowerment for democracy and good governance. Jananeethi \& Jananeethi Institute.

Shoichet, C.E. (2020, May 6). While she treated coronavirus patients, the US denied her a green card. CNN. https://www.cnn.com/2020/05/06/health/doctor-green-carddenied-coronavirus/index.html

Smith, N. (2015, October 13). It isn't just Asian immigrants who thrive in the U.S. Skilled foreign workers do well no matter where they're

from.

https://www.bloomberg.com/opinion/articles/2015-10-13/itisn-t-just-asian-immigrants-who-excel-in-the-u-s-

Smith, P. (2018). Learning to know, be, do, and live together with, in the cross-cultural experiences of immigrant teacher educators. Teaching and Teacher Education, 69, 263-274.

Smith, P. (2019). (Re)Positioning in the Englishes and (English) literacies of a Black immigrant youth: Towards a 'transraciolinguistic' approach. Theory into Practice, 58(3), 292-303. 
Smith, P. (2020). "How does a Black person speak English?”: Beyond American language norms. American Educational Research Journal, 57(1), 106-147.

Smith, P. (In press). (Ed.). Clarifying the role of race in the literacies of Black immigrant youth. Teachers College Record.

The White House. (2020a, April 22). Proclamation suspending entry of immigrants who present risk to the U.S. labor market during the economic recovery following the COVID-19 outbreak. https://www.whitehouse.gov/presidentialactions/proclamation-suspending-entry-immigrants-presentrisk-u-s-labor-market-economic-recovery-following-covid-19outbreak/

The White House. (2020b, June, 22). Proclamation suspending entry of aliens who present a risk to the U.S. labor market following the coronavirus outbreak. https://www.whitehouse.gov/presidentialactions/proclamation-suspending-entry-aliens-present-risk-us-labor-market-following-coronavirus-outbreak/

Yancy, C. W. (2020). COVID-19 and African Americans. Jama, 323(19):1891-1892. doi:10.1001/jama.2020.6548

Zariski, A. (2014). Legal literacy: An introduction to legal studies. Athabasca University: AU Press.

\section{Author Bios}

PATRIANN SMITH, PhD, is an Assistant Professor in the College of Education at the University of South Florida. Her major research interests lie in the area of Black immigrant Englishes/literacies, standardized and non-standardized English ideologies, multicultural teacher education, literacy assessment, and cross-cultural and cross-linguistic literacy practices. Email: psmith4@usf.edu

S. JOEL WARRICAN, PhD, is a Professor and the Director of the School of Education at The University of the West Indies, Cave Hill Campus. His major research interests include multiculturalism, cross-linguistic studies, diaspora literacy, and transformative education. Email: joel.warrican@cavehill.uwi.edu 